\title{
Cutaneous Malignancy due to Arsenicosis in Bangladesh: 12-Year Study in Tertiary Level Hospital
}

\author{
Md. Iqbal Mahmud Choudhury $\left(\mathbb{D},{ }^{1}\right.$ Nilufar Shabnam, ${ }^{2}$ Tazin Ahsan, ${ }^{3}$ \\ S. M. Abu Ahsan, ${ }^{4}$ Md. Saiful Kabir, ${ }^{5}$ Rashed Md. Khan, ${ }^{6}$ Md. Abdal Miah, ${ }^{7}$ \\ Mohd. Kamal Uddin, and Md. Aminur Rashid Liton' \\ ${ }^{1}$ Assistant Professor, Plastic Surgery Unit, Bangabandhu Sheikh Mujib Medical University (BSMMU), Dhaka, Bangladesh \\ ${ }^{2}$ Assistant Professor, Department of Surgery, BIRDEM Hospital and Ibrahim Medical College, Dhaka, Bangladesh \\ ${ }^{3}$ Honorary Medical Officer, Department of Surgery, Bangabandhu Sheikh Mujib Medical University (BSMMU), Dhaka, Bangladesh \\ ${ }^{4}$ Associate Professor and Head of the Department of Surgery, Ad-din Sakina Medical College, Jessore, Bangladesh \\ ${ }^{5}$ Professor and Head of Department of Dermatology and Venereology, National Medical College and Hospital, Dhaka, Bangladesh \\ ${ }^{6}$ Professor and Head of the Department of Dermatology \& VD, Dhaka Medical College Hospital, Dhaka, Bangladesh \\ ${ }^{7}$ Assistant Professor, Department of Dermatology and Venereology, Centre for Medical Education, Dhaka, Bangladesh \\ ${ }^{8}$ Senior Consultant, Department of Dermatology, 250 bedded General Hospital, Gopalganj, Bangladesh \\ ${ }^{9}$ Assistant Professor, Department of Dermatology and Venereology, Holy Family Red Crescent Medical College and Hospital, \\ Dhaka, Bangladesh
}

Correspondence should be addressed to Md. Iqbal Mahmud Choudhury; drimcrony@gmail.com

Received 28 October 2018; Accepted 3 December 2018; Published 16 December 2018

Guest Editor: Sajib Chakraborty

Copyright (C) 2018 Md. Iqbal Mahmud Choudhury et al. This is an open access article distributed under the Creative Commons Attribution License, which permits unrestricted use, distribution, and reproduction in any medium, provided the original work is properly cited.

Bangladesh is grappling with the largest mass poisoning of a population in the world due to contamination of drinking water with naturally occurring inorganic arsenic. It is estimated that 75 million people of 59 (out of 64) districts are at risk of drinking contaminated water with arsenic above $50 \mu \mathrm{g} / \mathrm{L}$. Long term exposure to arsenic causes cancers, including skin, lung, and bladder. This is a randomized prospective study to see the prevalence of skin cancer from arsenic affected area of Bangladesh, as well as their variation by geographical area, age, gender, location on the body, and socioeconomic conditions, in outpatient department of plastic surgery unit of Bangabandhu Sheikh Mujib Medical University (BSMMU). A total of 960 patients with skin cancers comprised of 528 males and 432 females were selected for the study from January 2004 to December 2015. In this 12-year study, we found squamous cell carcinoma, basal cell carcinoma, melanoma, and Merkel cell carcinoma to be associated with the ingestion of arsenic contaminated ground water. This is a reflection of a small part of the total national scenario of devastating result of arsenic mediated cancer in terms of skin malignancy. This study will help the future researchers who are contemplating to work on arsenic induced health problem.

\section{Introduction}

Arsenic contamination of ground water in Bangladesh is reported to be the worst problem in the world in terms of affected population [1, 2]. Survey data from 2000 to 2010 have demonstrated that an estimated 35 to 77 million Bangladeshi people, especially in rural area, have been chronically exposed to arsenic through drinking water and daily food [3-5]. Before 1970s, people in this country used surface water for drinking and daily activities. The surface water was pathogen laden and as a result they suffered from several types of diarrheal diseases in epidemic manner. To solve this problem, since 1970s, the government and other international organizations introduced shallow tube wells. The people got the apparent benefit but the hidden problem was discovered years later. The water from shallow tube wells (depth of 10$70 \mathrm{~m}$ ) contains arsenic in toxic level, which causes a lot of hazards to the human body. But ground water from deep 
tube wells (depths $>150 \mathrm{~m}$ ) is safe and contains arsenic in less concentration $[5,6]$.

According to WHO guidelines, water containing arsenic over $10 \mu \mathrm{g} / \mathrm{L}$ is said to be contaminated but in Bangladesh, this bench mark rises to $50 \mu \mathrm{g} / \mathrm{L}$ [7-12]. Natural Drinking Water Quality Survey report used an estimated population of 164 million to estimate that 22 million and 5.6 million people are drinking water with arsenic concentrations $>50 \mu \mathrm{g} / \mathrm{L}$ and $>200 \mu \mathrm{g} / \mathrm{L}$, respectively [13]. This can lead to massive chronic poisoning-called arsenicosis-causing neoplastic and nonneoplastic health problems in local population. This can occur at genetic and epigenetic level [14]. The arsenic biotransformation process which involves methylation changes is thought to play a key role for malignant transformation. Arsenic can damage DNA through oxidative stress by generation of toxic species such as reactive oxygen species (ROS) [10, 15-17]. According to the United States Environmental Protection Agency, the risk of developing skin cancer in association with daily consumption of around 1.0 liters of arsenic contaminated water at $50 \mu \mathrm{g} / \mathrm{L}$ concentration has been estimated to be 1 in 1000 to 2 in 1000[18]. Basal cell carcinoma (BCC) and squamous cell carcinoma (SCC) are the most common nonmelanotic cutaneous malignancy in patients with long term exposure to arsenic. Merkel's Cell Carcinoma (MCC), which is uncommon, and melanoma have been documented at low frequency [19-22].

In 1983, Krishna Chandra Shah identified arsenic induced skin lesions in India and by 1987, he detected several arsenic induced skin lesions in patients who came from neighboring Bangladesh. In 1993, the Public Health Engineering Department of Bangladesh officially declared the confirmation of arsenic contamination in Nawabganj district [23-25]. In 1998, British Geological Survey (BGS) collected water samples from 41 arsenic affected districts [26] and 35\% of water sample were found to have arsenic contamination above $50 \mu \mathrm{g} / \mathrm{L}$. The recent statistic on arsenic contamination indicates that 59 out of 64 districts of Bangladesh have been affected [27]. Approximately $85 \%$ area of Bangladesh has arsenic contaminated ground water and around 75 million people are at risk of arsenic ingestion from the tube-wells water [1]. Apart from the national survey there have been a number of thana and village surveys in many districts. The districts where most upazillas and villages have a large number of contaminated wells (up to 100\%) are termed as worst affected districts. Those districts are Chandpur (90\%), Munshiganj (83\%), Gopalganj (79\%), Brahmanbaria (70\%), Jhenaidah (69\%), Madaripur (69\%), Noakhali (69\%), Satkhira (67\%), Comilla (65\%), Shariatpur (65\%), Lakshmipur (64\%), Pabna (62\%), Meherpur (60\%), Bagerhat (60\%), and Natore (58\%). The least affected districts are the ones where none of the samples exceed the Bangladesh limit. They are Thakurgaon, Panchagarh, Nilphamari, Lalmonirhat, Patuakhali, Barguna, Barisal, Chuadanga, Jessore, Feni, Khulna, Magura, Narail, Rajbari, and Pirojpur [28]. In about half of the measurements, the arsenic concentration in tube-well water was about $50 \mu \mathrm{g} / \mathrm{L}[29,30]$, which reached above $150-300 \mu \mathrm{g} / \mathrm{L}$ in some districts or parts of some districts along the border of West Bengal, India [21, 31].
The occurrence of arsenic diseases depends on the ingestion of arsenic compounds and their excretion from the body. It has been reported that $40 \%$ to $60 \%$ arsenic can be retained by the human body $[32,33]$. The daily consumption of arsenic contaminated water is very high in Bangladesh, especially in villages. The villagers are more involved in manual labour and for the hard-work they consume more water (more than 5 liters per day), especially in the summer [1]. They retain arsenic not only by drinking water but by all of their food chains and cooked food which is contaminated by arsenic. We have almost no data to state exactly when the problem with arsenic poisoning started in Bangladesh, but it may be assumed that the consumption of arsenic contaminated water since 1970 is the beginning of the problem.

\section{Materials and Methods}

We performed a prospective study. Study period was from January 2004 to December 2015. The cases were selected random-wise from outpatient department (plastic surgery) of Bangabandhu Sheikh Mujib Medical University (BSMMU), Dhaka, Bangladesh. All the patients were referred from the department of dermatology of BSMMU, different medical colleges, and private chambers of dermatologists in Bangladesh with histopathology reports of incisional biopsy (incisional biopsy is a surgical procedure to remove a piece of tissue from a lesion or mass. The tissue is then tested by the histopathologists to find out what it is). All the lesions were larger than $2.5 \mathrm{~cm}$ in diameter and required plastic surgical maneuver, that is, wide excision and reconstruction by skin graft or flap coverage. We then sent the excisional biopsy (excisional biopsy is a surgical procedure in which whole lesion or mass is removed then tested to find out what it is) specimen for histopathology after marking its different borders with different suture materials (Prolene, Vicryl, and Silk) to delineate the exact area of the body from where we have removed it. We used a container containing $10 \%$ formalin to transport the specimen to the department of histopathology. The main target of this histopathology was to see the deep surface and marginal clearance of this excised specimen. The histopathologists did immunohistochemistry (immunohistochemistry refers to the process of detecting the antigens in the cells of tissue section by exploiting the principle of antibodies binding specifically to the antigens in the biological tissue) for Merkel Cell Tumour and Melanoma. The histopathologists did the diagnosis of the cancer by world-wide standard methods.

Within these 12 years, 1403 patients were found with cutaneous malignancy among which 1156 cases were related to arsenic exposure. 960 cases fulfilled the selection criteria (which are listed below) and 196 patients who had multiple lesions due to arsenicosis were not included in the study.

\subsection{Selection Criteria}

(i) Those who have one of the dichotomous physiciandiagnosed skin lesions [34],

Melanosis, Keratosis, Hyperkeratosis, and Leucomelanosis 
TABLE 1: Demographic analysis of patients.

\begin{tabular}{lccc}
\hline & Male & Female & Total \\
\hline Number of Patients (\%) & $528(55)$ & $432(45)$ & $960(100)$ \\
P value & $\chi^{2} \mathrm{p}=0.22$ & $\chi^{2} \mathrm{p}=0.09$ & $\chi^{2} \mathrm{p}=0.13$ \\
\hline Age (Mean and SD) & $49.1 \& 12.11$ & $46.6 \& 13.3$ & $47.8 \& 12.76$ \\
\hline Age (Median) & 64 & 69 & 67 \\
\hline Age Range & $20-90$ & $18-95$ & $18-95$ \\
\hline Family history of cutaneous malignancy due to arsenicosis & $268(27.92)$ & $252(26.25)$ & $520(54.17)$ \\
\hline
\end{tabular}

(Melanosis is termed as a diffuse or spotted lesion characterized by dark pigmentation on the face, neck, limbs and trunk. Keratosis is defined as any diffuse or spotted lesion characterized by hard and roughened skin elevations observed on the hands and feet. Hyperkeratosis is defined as extensively thickened keratosis observed on the hands and/or feet that are easily visible from a distance. Leucomelanosis is defined as depigmentation characterized by black and white spots present anywhere in the body)

(ii) History of ingestion of water from tube-wells for at least 10 years in arsenic prevalent districts marked by the government of Bangladesh

(iii) Patients with single malignant lesion with histopathology report of incisional biopsy

Statistical analysis was performed using SPS 16.0 software. Normally distributed continuous variables were expressed and categorical variables were expressed as numbers and percentages. Mann-Whitney $U$ test used in comparison with the continuous variables and chi-square test was used in comparison with categorical variables. The level of statistical significance was considered as $<0.05$.

Ethical approval was taken from Institutional Review Board (IRB), BSMMU. The declaration of Helsinki was followed. All the patients were involved in the study after taking informed written consent. All the information was collected using a questionnaire by face to face interview.

\section{Results}

A sample of 960 patients from January 2004 to December 2015 presenting with cutaneous malignancy (single lesion) from different arsenic contaminated districts of Bangladesh. There were 528 (55\%) male and 432 (45\%) female. The mean age of patients was $47.8 \pm 12.76$ years (male $49.1 \pm 12.11$ and female $46.6 \pm 13.3$ ). About 520 patients have family history of malignancy due to arsenicosis (Table 1).

Cancers were very less below the age of 24 . Higher prevalence $(28.99 \%)$ of patients was noted in $40-49$ years age group which was found to be statistically significant ( $\mathrm{P}$ $<0.05)$. BCC was found in $563(58.65 \%)$ cases, SCC in 384 (40\%), melanoma in $11(1.15 \%)$, and MCC in $2(0.21 \%)$ cases. There was no statistically significant difference between male and female population. Melanomas were found in above 40 years of age and more in male $(0.73 \%)$ population. Two MCC cases were found in the female population (Table 2).
In Table 3, face (10.31\%) was least affected area where limbs (34.27\%) were most. There was a statistically significant $(\mathrm{P}<0.05)$ difference between male and female patients. 270 (28.13\%) lesions were found on the scalp and $262(27.29 \%)$ were in the trunk. About $78.56 \%$ (754) patients came from low education level, whereas $3.64 \%$ (35) in high education level, which was found to be statistically significant $(\mathrm{P}<0.05)$. Melanomas were more among the lower educational group where MCCs were found in the educated group (Table 4).

In Tables 5(a) and 5(b), highest ( $\mathrm{n}=67,6.98 \%)$ number of patients came from Chandpur ( $90 \%$ affected area) and all types of cancer (BCC, SCC, Melanoma, and MCC) are found in this area. The lowest number of patient $(n=11,1.15 \%)$ came from Pirojpur and Patuakhali $(\mathrm{P}<0.05)$. About $66.55 \%$ $(\mathrm{N}=637)$ patient came from worst affected districts with 35.22\% ( $\mathrm{N}=338)$ BCC, $29.83 \%(\mathrm{~N}=286)$ SCC, $1.14 \%(\mathrm{~N}=11)$ melanoma, and $0.21 \%(\mathrm{~N}=2) \mathrm{MCC}$. But from the least affected areas only $33.65 \%(\mathrm{~N}=323)$ came with $23.44 \%(\mathrm{~N}=225)$ BCC and $10.21 \%(\mathrm{~N}=95)$ SCC. No melanoma or MCC was found in the least affected districts.

\section{Discussion}

Arsenic (As) is a metalloid. It is widely distributed in nature [35]. Arsenic compounds can be found in organic (when combined with carbon and hydrogen) and inorganic form (when combined with oxygen, chlorine, and sulfur among other elements) [36]. In Environment, arsenic can be found with an oxidation state +3 (Arsenite or, As [III]), or, +5 (Arsenate or As $[\mathrm{V}]$ ), exhibiting different grades of toxicity [37]. An increased level of inorganic arsenic in drinking water is the major cause of arsenic toxicity [36, 38]. For this reason, IARC (International Agency for Research on Cancer) declared that arsenic is a human carcinogen (class I) and recommended threshold for arsenic concentration of drinking water $\leq 10 \mu \mathrm{g} / \mathrm{L}$ [39-41]. Smith $\mathrm{AD}$ et al. also showed arsenic levels as low as $2 \mu \mathrm{g} / \mathrm{L}$ may be cancerous [42].

It is now widely believed that high arsenic levels in ground water in Bangladesh have natural geological source which may be due to abstraction of quaternary confined and semiconfined alluvial or deltaic aquifers. This is also inferred that arsenic is occurring in the alluvial sediments; the ultimate origin is perhaps in the out crops of hard rocks higher up the Ganga catchment [43]. A large number of chemical and biological reactions, namely, oxidation, reduction, adsorption, precipitation, methylation, and volatilization, participate in the cycling of the toxic element in ground water [35]. It is 


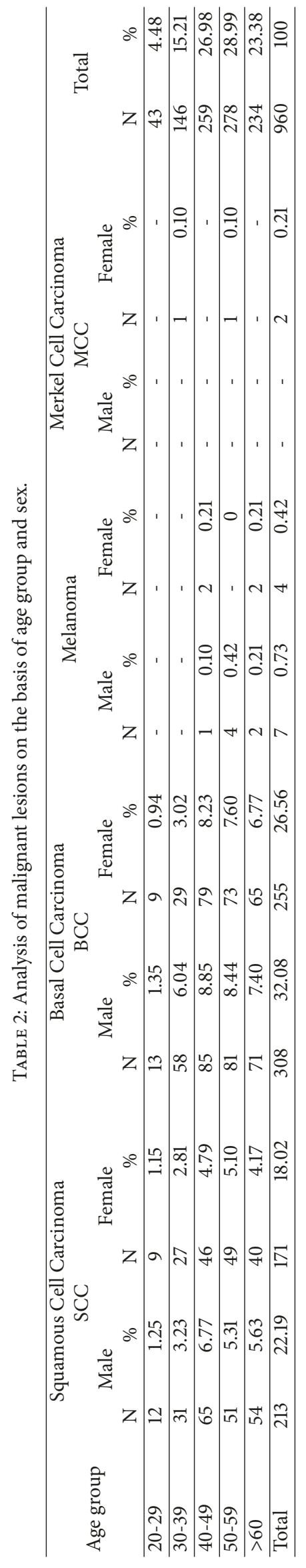


TABLE 3: Age and sex variation according to the location of lesion.

\begin{tabular}{|c|c|c|c|c|c|c|c|c|c|c|c|c|c|c|c|c|}
\hline \multirow{3}{*}{ Age Group (yrs) } & \multicolumn{4}{|c|}{ Face } & \multicolumn{4}{|c|}{ Scalp } & \multicolumn{4}{|c|}{ Limbs } & \multicolumn{4}{|c|}{ Trunk } \\
\hline & \multicolumn{2}{|c|}{ Male } & \multicolumn{2}{|c|}{ Female } & \multicolumn{2}{|c|}{ Male } & \multicolumn{2}{|c|}{ Female } & \multicolumn{2}{|c|}{ Male } & \multicolumn{2}{|c|}{ Female } & \multicolumn{2}{|c|}{ Male } & \multicolumn{2}{|c|}{ Female } \\
\hline & $\mathrm{N}$ & $\%$ & $\mathrm{~N}$ & $\%$ & $\mathrm{~N}$ & $\%$ & $\mathrm{~N}$ & $\%$ & $\mathrm{~N}$ & $\%$ & $\mathrm{~N}$ & $\%$ & $\mathrm{~N}$ & $\%$ & $\mathrm{~N}$ & $\%$ \\
\hline $20-29$ & 4 & 0.42 & 2 & 0.21 & 5 & 0.52 & 4 & 0.42 & 11 & 1.15 & 5 & 0.52 & 5 & 0.52 & 7 & 0.73 \\
\hline $30-39$ & 13 & 1.35 & 7 & 0.73 & 17 & 1.77 & 13 & 1.35 & 35 & 3.65 & 17 & 1.77 & 24 & 2.50 & 20 & 2.08 \\
\hline $40-49$ & 14 & 1.46 & 8 & 0.83 & 57 & 5.93 & 26 & 2.71 & 53 & 5.52 & 40 & 4.17 & 27 & 2.81 & 53 & 5.53 \\
\hline $50-59$ & 8 & 0.83 & 11 & 1.15 & 52 & 5.42 & 32 & 3.33 & 39 & 4.06 & 51 & 5.31 & 37 & 3.85 & 29 & 3.02 \\
\hline$>60$ & 11 & 1.15 & 21 & 2.19 & 41 & 4.27 & 23 & 2.40 & 48 & 4.99 & 30 & 3.13 & 27 & 2.81 & 33 & 3.44 \\
\hline Total & 50 & 5.21 & 49 & 5.11 & 172 & 17.91 & 98 & 10.21 & 186 & 19.37 & 143 & 14.9 & 120 & 12.49 & 142 & 14.8 \\
\hline
\end{tabular}

TABLE 4: Analysis of patients according to education level.

\begin{tabular}{|c|c|c|c|c|c|c|c|c|c|c|c|c|}
\hline \multirow{3}{*}{ Patient } & \multicolumn{4}{|c|}{ None-primary } & \multicolumn{4}{|c|}{ Secondary-College } & \multicolumn{4}{|c|}{ Graduation or, further } \\
\hline & \multicolumn{2}{|c|}{ Male } & \multicolumn{2}{|c|}{ Female } & \multicolumn{2}{|c|}{ Male } & \multicolumn{2}{|c|}{ Female } & \multicolumn{2}{|c|}{ Male } & \multicolumn{2}{|c|}{ Female } \\
\hline & $\mathrm{N}$ & $\%$ & $\mathrm{~N}$ & $\%$ & $\mathrm{~N}$ & $\%$ & $\mathrm{~N}$ & $\%$ & $\mathrm{~N}$ & $\%$ & $\mathrm{~N}$ & $\%$ \\
\hline SCC & 173 & 18.02 & 136 & 14.17 & 38 & 3.96 & 30 & 3.13 & 4 & 0.42 & 3 & 0.31 \\
\hline $\mathrm{BCC}$ & 237 & 24.69 & 198 & 20.63 & 57 & 5.94 & 45 & 4.69 & 14 & 1.46 & 12 & 1.25 \\
\hline Melanoma & 6 & 0.63 & 4 & 0.42 & - & - & - & - & 1 & 0.10 & - & - \\
\hline MCC & - & - & - & - & - & - & 1 & 0.10 & - & - & 1 & 0.10 \\
\hline Total & 416 & 43.34 & 338 & 35.22 & 95 & 9.90 & 76 & 7.92 & 19 & 1.98 & 16 & 1.66 \\
\hline
\end{tabular}

also manmade causes; i.e., the use of fertilizers, pesticides, insecticides, waste disposal, and arsenic treated wooden poles for power grids was blamed for the contamination [28]. That underground water system flows into shallow tube wells used by many. The water pulled to the surface from the wells is often contaminated with high levels of arsenic- causing problems in food chain [44].

Arsenic toxicity is close dependent and particularly on the amount of ingestion of arsenic compounds and their excretion from the body through urine, stool, skin, hair, nail, and breath. It has been reported that 40\%-60\% arsenic is retained in human body and passes slowly out through skin and nail [33]. Both arsenite and arsenate accumulate in dermis and epidermis, epidermal stem cells, have been proposed as a potential target for arsenic induced carcinogenesis [31, 45, 46]. Arsenic also has the potential to induce malignant transformation of human keratinocyte [47]. The carcinogenic mechanism in the cell includes the following: (a) biotransformation, methylation can activate the toxic and carcinogenic potential of arsenic [48, 49]; (b) arsenic induced oxidative stress, such as reactive oxygen species (ROS) leading to genomic alteration [50-53]; (C) epigenetic changes, DNA methylation, histone modification, and micro-RNAg [54, 55]. Moreover, malnutrition which is basically due to poverty of this region has a great effect on immunosuppression, causing arsenic induced malignancy [26]

In this 12 years study, we found 960 patients with cutaneous malignancy where the mean age was 47.8 years and showed male predominance. Basal Cell Carcinoma (BCC) was 58.65\% ( $=563)$ and Squamous Cell Carcinoma (SCC) was $40 \%(\mathrm{~N}=384)$ of the study population. Ghosh SK et al. did a field study from July to August 2013, on arsenic contaminated area of West Bengal, India, where the mean age was 52.2 years, $37.5 \%$ BCC and $41.7 \%$ SCC. This result is nearly identical to our study probably due to similar geographical location, genetic constitution of the people, and mode of contamination of ground water in both the regions [56]. A similar study conducted in India supported our finding of male predominance. This could be explained by the observation that males of the rural areas of this region are more engaged in manual labour (day labourer, farmer, rickshaw puller, etc.) and consume more water per day than the females [57]. About 54.17\% ( $\mathrm{N}=520)$ patient had positive family history of cutaneous malignancy due to arsenicosis. This fact maybe attributed to the use of water (drinking, cooking, and other purposes) obtained from the same tube well by all the members of a family. Majority of the people of rural area of Bangladesh live in poverty, and they have to use only one common tube well for many families [58].

We found $1.15 \%(\mathrm{~N}-11)$ melanoma patients in our study, highest in 50-59-year age group. Melanoma is a relatively rare finding in other studies of the world. All the melanoma were located in the lower limbs, especially on sole and toe nail, found mainly in Chandpur, Gopalganj, Madaripur, and Sariatpur where the arsenic concentration is $>50 \mu \mathrm{g} / \mathrm{L}$, sometimes even up to $500 \mu \mathrm{g} / \mathrm{L}$ in some villages [29]. A study conducted in Iowa, IA, USA, suggested a potential link between elevated arsenic levels and melanoma, found mostly in patients aged $>40$ years. They suggested that arsenic's affinity for sulfhydryl group of keratin causes accumulation where scleroprotein is abundant, e.g., finger nails and toe nails. It is found when average arsenic concentration was $21 \mu \mathrm{g} / \mathrm{L}[19,59-61]$.

In our series, we found $0.21 \%(\mathrm{~N}-$ 02) Merkel Cell Carcinoma (MCC) in the temporal region (sun exposed area) 


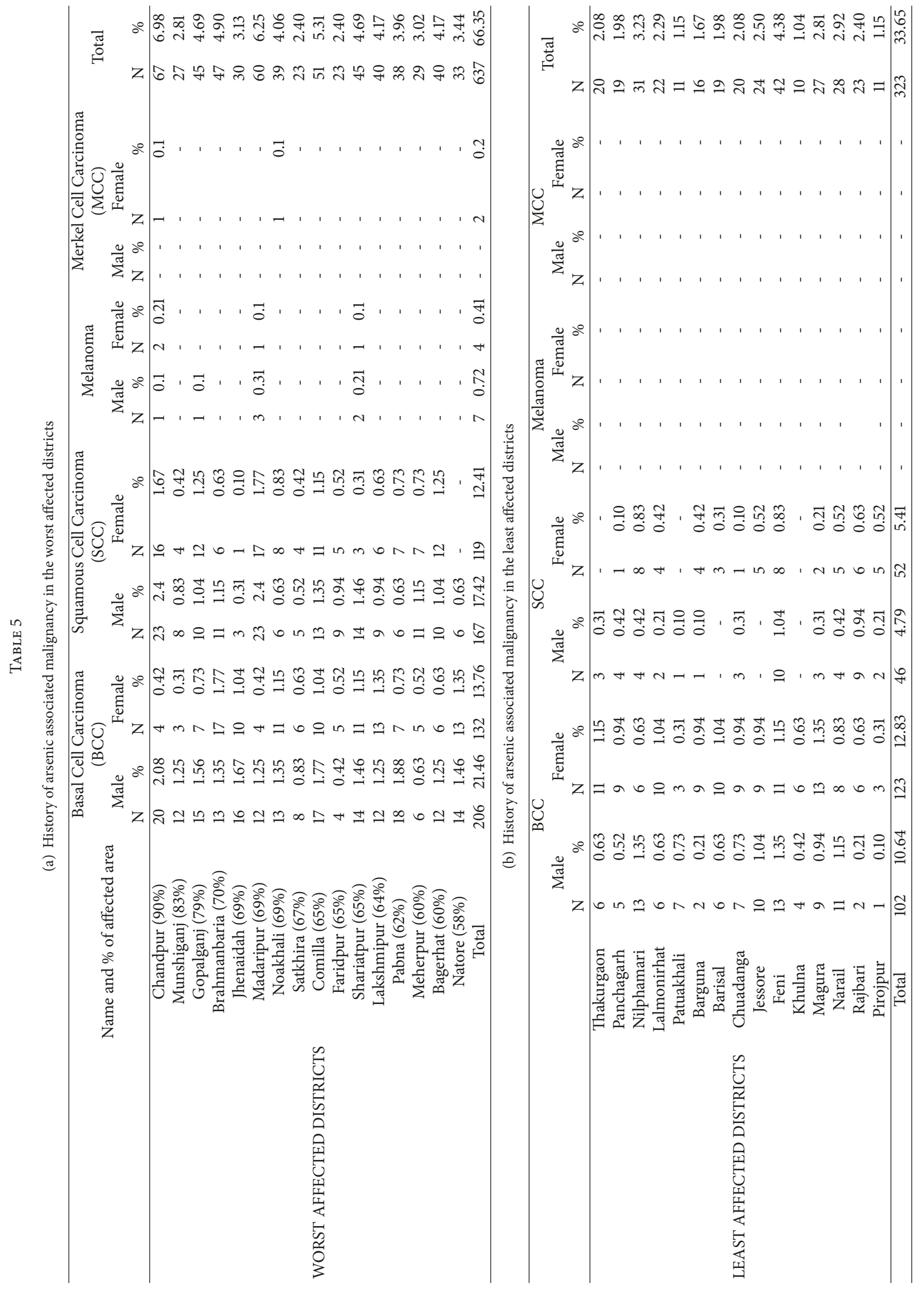


of two female patients hailing from Chandpur and Noakhali, where contaminated water contain high concentration of arsenic (>300 $\mu \mathrm{g} / \mathrm{L})$. MCC is normally related to advanced age, sun exposure, and immunosuppression [62]. Ho SY et al. conducted a study in Taiwan and found three cases of MCC with history of ingestion of arsenic contaminated water more than $50 \mu \mathrm{g} / \mathrm{L}$ (3.5 liters daily for male and 2.0 liters for female) with average duration of 20 years [63].

We found limb to be the most affected region $(34.27 \%$, $\mathrm{N}=329)$, followed by scalp $(28.13 \%, \mathrm{~N}=270)$. Face is the least affected area $(10.31 \%, \mathrm{~N}=99)$. But nonarsenic mediated cancer especially BCC affects the face [64]. Limbs, scalp, and trunk are more affected probably due to hair, which accumulate arsenic and cause malignant changes in the area [61].

More than three-fourth patients in our study $(78.56 \%$, $\mathrm{N}=754$ ) had education up to primary level or below, which is supported by another study in Bangladesh, where 69\% patients studied up to primary level or below [34]. People of this education level suffer more from arsenic mediated cancer due to lack of knowledge, minimum perception to counseling, low financial capability for treatment, fail to take part in mitigation program, superstition, and malnutrition. They are mostly manual labourers, consuming more than 5 liters of arsenic contaminated water per day [1]. Cancer risk associated with daily consumption of 1.0 liter of water with organic arsenic $(50 \mu \mathrm{g} / \mathrm{L})$ has been estimated [18]. Malnutrition also plays a role in the pathogenesis of cancer by reducing the immunity [26].

\section{Conclusion}

Our study was aimed at presenting the prevalence of arsenic associated skin malignancy in patients coming to the plastic surgery outpatient department of BSMMU, a tertiary level hospital in Dhaka. This study shows only a small part of the national problem. Only the patients with detected cutaneous malignancy, large enough (more than $2.5 \mathrm{~cm}$ in diameter) to require plastic surgical maneuver, were included, so a large number of patients with smaller lesions were beyond the scope of this study. The problem of arsenic exposure has started since the 1970s and a considerable amount of time has gone by since then, as a result a large number of people have become affected by arsenic associated skin malignancy. These patients only represent a portion of the total population. Many others with smaller sized lesions or precancerous lesions do not even present themselves at the proper place. The big number of skin malignancies of this small study population is very alarming and could be the tip of the ice-berg of the real problem. Future studies should be targeted at developing a nation-wide screening and management protocol in different levels of hospitals, both by the government and the nongovernment organizations. Drawing the attention of the concerned policymakers is really vital in this regard.

\section{Data Availability}

The data used to support the findings of this study are available from the corresponding author upon request.

\section{Conflicts of Interest}

The authors declare that there are no conflicts of interest regarding the publication of this paper.

\section{References}

[1] M. Saifuddin and M. M. Karim, "Groundwater Arsenic Contamination in Bangladesh: Causes, Effects and Remedation," in Proceedings of the 1st IEB international conference and 7th annual paper meet, Chittagong, 2001.

[2] S. A. Talukder, A. Chatterjee, J. Zheng et al., "Studies of Drinking Water Quality and Arsenic Calamity in Groundwater of Bangladesh," in Studies of Drinking Water Quality and Arsenic Calamity in Groundwater of Bangladesh Proceedings of the International Conference on Arsenic Pollution of Groundwater in Bangladesh: Causes, Effects and Remedies, Dhaka, Bangladesh, 1998.

[3] S. V. Flangan, R. B. Johnston, and Y. Zheng, "Arsenic in tube well in Bangladesh: health and economic impacts and implications for arsenic mitigation," Bulletin of the World Health Organization, 2012.

[4] New Nation Report, "Immediate Government Steps Needed, Millions Affected by Arsenic Contamination," The New Nation, A daily newspaper of Bangladesh, 1996.

[5] D. G. Kinninburgh and P. L. Smedley, Eds., Arsenic contamination of groundwater in Bangladesh, British Geological Survey, Keyworth, 2001.

[6] Multiple Indicator Cluster Survey (MICS), New York: United Nations Children's Fund, Bangladesh \& Bangladesh Bureau of statistics; 2010, 2009, http://www.unicef.org/bangladesh/knowledgecentre_6292.htm.

[7] M. Argos, T. Kalra, B. L. Pierce et al., "A prospective study of arsenic exposure from drinking water and incidence of skin lesions in Bangladesh," American Journal of Epidemiology, vol. 174, no. 2, pp. 185-194, 2011.

[8] “WHO Guidelines for Drinking-Water Quality. Vol. 2," Health Criteria and Other Supporting Information.

[9] S. J. Ryker, "Mapping arsenic in groundwater," Geotimes, vol. 46, pp. 34-36, 2001.

[10] V. D. Martinez, E. A. Vucic, D. D. Becker-Santos et al., "Arsenic Exposure and the Induction of Human Cancers," Journal of Toxicology, vol. 2011, Article ID 431287, 13 pages, 2011.

[11] World Health Organisation (WHO), WHO Guidelines for Drinking-Water Quality, WHO, Geneva, Switzerland, 1993.

[12] B. K. Caldwell, W. T. Smith, and K. Lokuge, "Access to drinkingwater and arsenicosis in Bangladesh," Journal of Health, Population and Nutrition, vol. 24, pp. 336-345, 2006.

[13] Bangladesh national drinking water quality survey 2009, Dhaka: United Nations Children's Fund, Bangladesh, 2011, http://www .unicef.org/bangladesh/knowledgecentre_6868.htm.

[14] G. Marshall, C. Ferreccio, Y. Yuan et al., "Fifty-Year study of lung and bladder cancer mortality in Chile related to arsenic in drinking water," Journal of the National Cancer Institute, vol. 99, no. 12, pp. 920-928, 2007.

[15] P. P. Simeonova and M. I. Luster, "Mechanisms of arsenic carcinogenicity: Genetic or epigenetic mechanisms?" Journal of Environmental Pathology, Toxicology and Oncology, vol. 19, no. 3, pp. 281-286, 2000.

[16] C.-J. Chen and C.-J. Wang, "Ecological correlation between arsenic level in well water and age-adjusted mortality from 
malignant neoplasms," Cancer Research, vol. 50, no. 17, pp. 5470-5474, 1990.

[17] W. Cullen, B. McBride, and J. Reglinski, "The reaction of methylarsenicals with thiols: Some biological implications," Journal of Inorganic Biochemistry, vol. 21, no. 3, pp. 179-193, 1984.

[18] H. H. Wong and J. Wang, "Merkel cell carcinoma," Archives of Pathology \& Laboratory Medicine, vol. 134, no. 11, pp. 1711-1716, 2010.

[19] W. Boonchai, A. Green, J. Ng, A. Dicker, and G. ChenevixTrench, "Basal cell carcinoma in chronic arsenicism occurring in Queensland, Australia, after ingestion of an asthma medication," Journal of the American Academy of Dermatology, vol. 43, no. 4, pp. 664-669, 2000.

[20] H.-C. Lien, T.-F. Tsai, Yu Yun Lee, and C.-H. Hsiao, "Merkel cell carcinoma and chronic arsenicism," Journal of the American Academy of Dermatology, vol. 41, no. 4, pp. 641-643, 1999.

[21] S. S. Wong, K. C. Tan, and C. L. Goh, "Cutaneous manifestations of chronic arsenicism: Review of seventeen cases," Journal of the American Academy of Dermatology, vol. 38, no. 2 I, pp. 179-185, 1998.

[22] M. Rahman, "Arsenic and contamination of drinking water in Bangladesh: A public health perspective," Journal of Health, Population and Nutrition, vol. 20, pp. 193-197, 2002.

[23] K. C. Saha, "Chronic arsenical dermatoses from tube-well water in West Bengal during 1983-1987," Indian Journal of Dermatology, vol. 40, pp. 1-12, 1995.

[24] S. M. Ullah, "Arsenic contamination of ground water and irrigated soils of Bangladesh," in Processing of the International Conference on Arsenic Pollution of Ground Water in Bangladesh: Causes, Effects, and Remedies, Jadavpur University, Calcutta, Dhaka, 1998.

[25] A. H. Smith, E. O. Lingas, and M. Rahman, "Contamination of drinking-water by arsenic in Bangladesh: a public health emergency," Bulletin of the World Health Organization, vol. 78, no. 9, pp. 1093-1103, 2003.

[26] Daily Star Report, "An Urgent Call to Save a Nation," The Daily Star, A national daily newspaper of Bangladesh, 1999.

[27] "Arsenic, Banglapedia-National Encyclopedia of Bangladesh," http://en.banglapedia.org/index.php?title=Arsenic\&amp;oldid= 378.

[28] M. G. Alam, G. Allinson, F. Stagnitti et al., "rsenic contamination in Bangladesh groundwater: a major environmental and social disaster," International Journal of Environmental Health Research, vol. 12, no. 3, pp. 235-253, 2002.

[29] Country situation report: arsenic in drinking water in Bangladesh, 1996: a challenge in near future, World Health Organization, Geneva, 1996.

[30] Executive summary of the main report of Phase I, ground water and arsenic contamination in Bangladesh. British Geological Survey And Mott MacDonald (UK) for the Government of Bangladesh, Ministry of local Government, Rural Development and Cooperatives, Department of Public Health Engineering, and Department of International Development (UK), 1999, http://www.damient-consul.co.jp/english/arenic/article/ DFID-sum.html.

[31] T. J. Patterson and R. H. Rice, "Arsenite and insulin exhibit opposing effects on epidermal growth factor receptor and keratinocyte proliferative potential," Toxicology and Applied Pharmacology, vol. 221, no. 1, pp. 119-128, 2007.
[32] J. G. Farmer and L. R. Johnson, "Assessment of occupational exposure to inorganic arsenic based on urinary concentrations and speciation of arsenic.", Occupational and Environmental Medicine, vol. 47, no. 5, pp. 342-348, 1990.

[33] W. J. Seow, W.-C. Pan, M. L. Kile et al., "Arsenic reduction in drinking water and improvement in skin lesions: A follow-up study in Bangladesh," Environmental Health Perspectives, vol. 120, no. 12, pp. 1733-1738, 2012.

[34] M. S. Islam and F. Islam, "Arsenic Contamination in Groundwater in Bangladesh: An environmental and Social Disaster," in IWA Water Wiki, 2010, http://www.iwaterwiki.org/.

[35] Agency for Toxic Substances and Disease Registry (ATSDR), Toxicological Profile for Arsenic, U.S Department of Health and Human Services, Washington, DC, USA, 2007.

[36] M. Vahter, "Mechanisms of arsenic biotransformation," Toxicology, vol. 181-182, pp. 211-217, 2002.

[37] D. N. G. Mazumder, Diagnosis and treatment of chronic arsenic poisoning, United Nations Synthesis Report on Arsenic in Drinking Water, 2000.

[38] "Interantional Agency for Research on Cancer (IARC) Some drinking-water disinfectants and contaminants, including arsenic. Monographs on chloramines, chloral and chloral hydrate, dichloroacetic acid, trichloroacetic acid and 3chloro-4-(dichloromethyl)-5-hydroxy-2(5H)-furanone," IARC Monographs on the Evaluation of Carcinogenic Risks to Humans, vol. 84, pp. 269-477, 2004.

[39] R. H. McCuen, "Guidelines for drinking-water quality," Journal of the American Water Resources Association, vol. 38, no. 3, p. 879, 2002.

[40] U.S. Environmental Protection Agency (EPA) National Primary Drinking Water Regulation. Arsenic and Clarifications to compliance and New Source Contaminants Monitoring, in Final rule. Delay of effective date, Federal Registry, 2001.

[41] A. H. Smith, C. Hopenhayn-Rich, M. N. Bates et al., "Cancer Risks from Arsenic in Drinking Water," Environmental Health Perspectives, vol. 97, p. 259, 1992.

[42] M. M. Karim, Y. Komori, and M. Alam, "Subsurface Arsenic Occurrence and Depth of Contamination in Bangladesh," Journal of Environmental Chemistry, vol. 7, no. 4, pp. 783-792, 1997.

[43] S. M. I. Huq, J. C. Joardar, S. Parvin, R. Correll, and R. Naidu, "Arsenic contamination in food-chain: Transfer of arsenic into food materials through groundwater irrigation," Journal of Health, Population and Nutrition, vol. 24, no. 3, pp. 305-316, 2006.

[44] S. Ouypornkochagorn and J. Feldmann, "Dermal uptake of arsenic through human skin depends strongly on its speciation," Environmental Science \& Technology, vol. 44, no. 10, pp. 39723978, 2010.

[45] T. J. Patterson, T. V. Reznikova, M. A. Phillips, and R. H. Rice, "Arsenite maintains germinative state in cultured human epidermal cells," Toxicology and Applied Pharmacology, vol. 207, no. 1, pp. 69-77, 2005.

[46] S.-J. Wei, C. S. Trempus, R. E. Cannon, C. D. Bortner, and R. W. Tennant, "Identification of Dss1 as a 12-Otetradecanoylphorbol-13-acetate-responsive gene expressed in keratinocyte progenitor cells, with possible involvement in early skin tumorigenesis," The Journal of Biological Chemistry, vol. 278, no. 3, pp. 1758-1768, 2003.

[47] M. Stýblo, Z. Drobná, I. Jaspers, S. Lin, and D. J. Thomas, “The role of biomethylation in toxicity and carcinogenicity of arsenic: A research update," Environmental Health Perspectives, vol. 110, no. 5, pp. 767-771, 2002. 
[48] D. J. Thomas, M. Styblo, and S. Lin, “The cellular metabolism and systemic toxicity of arsenic," Toxicology and Applied Pharmacology, vol. 176, no. 2, pp. 127-144, 2001.

[49] M. Kessel, S. X. Liu, A. Xu, R. Santella, and T. K. Hei, "Arsenic induces oxidative DNA damage in mammalian cells," Molecular and Cellular Biochemistry, vol. 234-235, pp. 301-308, 2002.

[50] K. T. Kitchin, "Recent advances in arsenic carcinogenesis: modes of action, animal model systems, and methylated arsenic metabolites," Toxicology and Applied Pharmacology, vol. 172, no. 3, pp. 249-261, 2001.

[51] Y. An, Z. Gao, Z. Wang et al., "Immunohistochemical analysis of oxidative DNA damage in arsenic-related human skin samples from arsenic-contaminated area of China," Cancer Letters, vol. 214, no. 1, pp. 11-18, 2004.

[52] M. Matsui, C. Nishigori, S. Toyokuni et al., "The role of oxidative DNA damage in human arsenic carcinogenesis: Detection of 8hydroxy-2'-deoxyguanosine in arsenic-related Bowen's disease," Journal of Investigative Dermatology, vol. 113, no. 1, pp. 26-31, 1999.

[53] X. Ren, C. M. Mchale, C. F. Skibola, A. H. Smith, M. T. Smith, and L. Zhang, "An emerging role for epigenetic dysregulation in arsenic toxicity and carcinogenesis," Environmental Health Perspectives, vol. 119, no. 1, pp. 11-19, 2011.

[54] J. F. Reichard and A. Puga, "Effects of arsenic exposure on DNA methylation and epigenetic gene regulation," Epigenomics, vol. 2, no. 1, pp. 87-104, 2010.

[55] S. K. Ghosh, D. Bandyopadhyay, S. K. Bandyopadhyay, and K. Debbarma, "Cutaneous malignant and premalignant conditions caused by chronic arsenicosis from contaminated ground water consumption: a profile of patients from eastern India.," SKINmed Journal, vol. 11, no. 4, pp. 211-216, 2013.

[56] D. N. Guha Mazumder, R. Haque, N. Ghosh et al., "Arsenic levels in drinking water and the prevalence of skin lesions in West Bengal, India," International Journal of Epidemiology, vol. 27, no. 5, pp. 871-877, 1998.

[57] H. Ahsan, Y. Chen, F. Parvez et al., "Arsenic exposure from drinking water and risk of premalignant skin lesions in Bangladesh: baseline results from the health effects of arsenic longitudinal study," American Journal of Epidemiology, vol. 163, no. 12, pp. 1138-1148, 2006.

[58] W. E. Morton and D. A. Dunnette, "Health effects of environmental arsenic," in Arsenic in the environment, Part II : human health and ecosystem effects, J. O. Nriagu, Ed., John Wiley \& Sons, New York, 1994.

[59] C. Watanabe, T. Inaoka, T. Kadono et al., "Males in rural Bangladeshi communities are more susceptible to chronic arsenic poisoning than females: Analyses based on urinary arsenic," Environmental Health Perspectives, vol. 109, no. 12, pp. 1265-1270, 2001.

[60] L. E. B. Freeman, L. K. Dennis, C. F. Lynch, P. S. Thorne, and C. L. Just, "Toenail arsenic content and cutaneous melanoma in Iowa," American Journal of Epidemiology, vol. 160, no. 7, pp. 679-687, 2004.

[61] M. L. Heath, N. Jaimes, B. Lemos et al., "Clinical characteristics of Merkel cell carcinoma at diagnosis in 195 patients: the AEIOU features," Journal of the American Academy of Dermatology, vol. 58, no. 3, pp. 375-381, 2008.

[62] S.-Y. Ho, Y.-C. Tsai, M.-C. Lee, and H.-R. Guo, "Merkel cell carcinoma in patients with long-term ingestion of arsenic," Journal of Occupational Health, vol. 47, no. 2, pp. 188-192, 2005.
[63] L. Sartore, L. Lancerotto, M. Salmaso et al., "Facial basal cell carcinoma: Analysis of recurrence and follow-up strategies," Oncology Reports, vol. 26, no. 6, pp. 1423-1429, 2011.

[64] Y. Ö. Tiftikcioǧlu, Ö. Karaaslan, H. M. Aksoy, B. Aksoy, and U. Koçer, "Basal cell carcinoma in Turkey," The Journal of Dermatology, vol. 33, no. 2, pp. 91-95, 2006. 


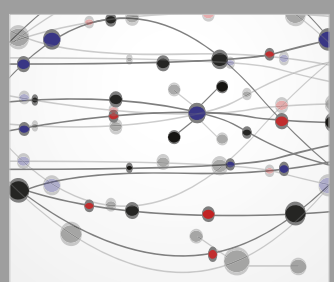

The Scientific World Journal
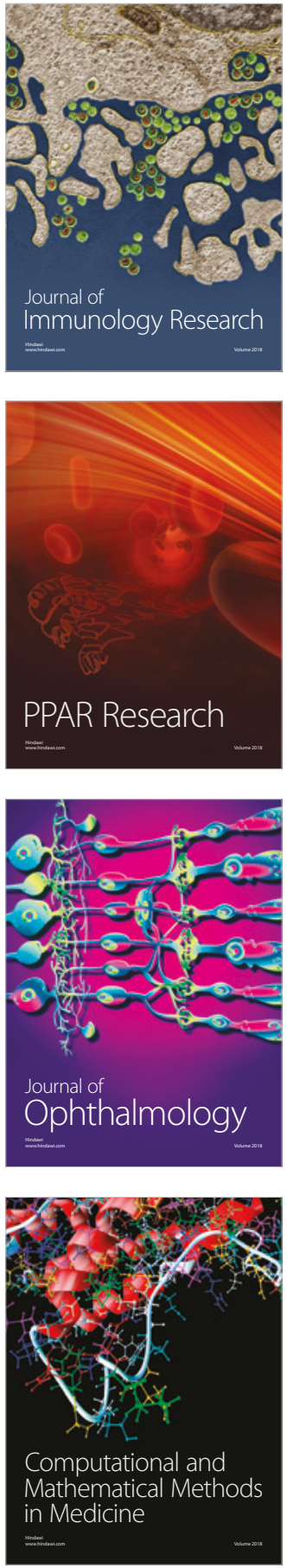

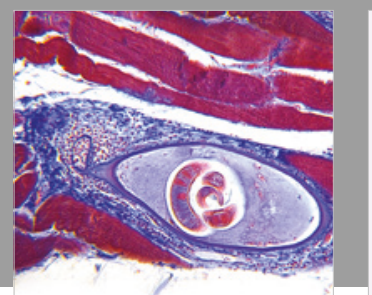

Gastroenterology Research and Practice

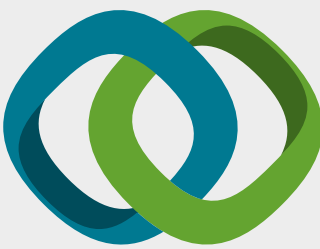

\section{Hindawi}

Submit your manuscripts at

www.hindawi.com
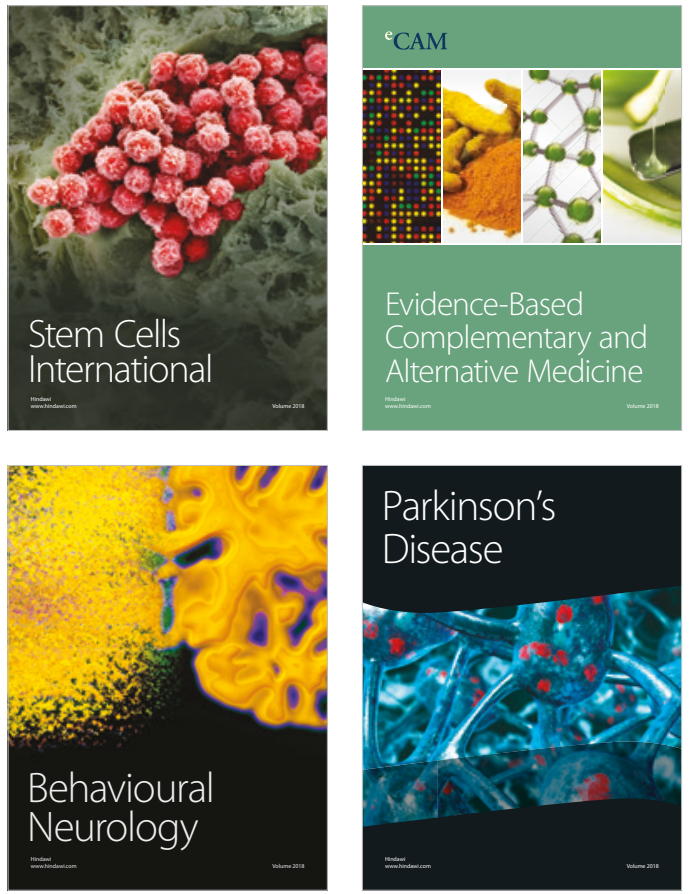

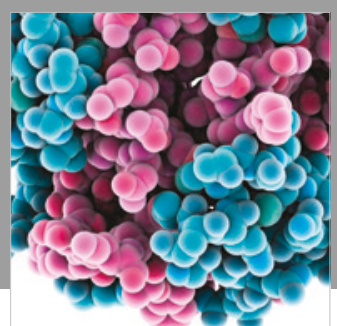

ournal of

Diabetes Research

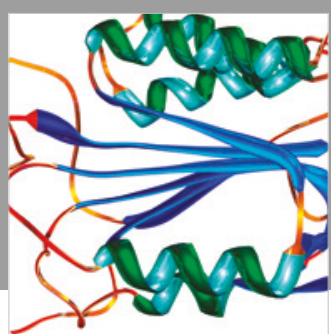

Disease Markers
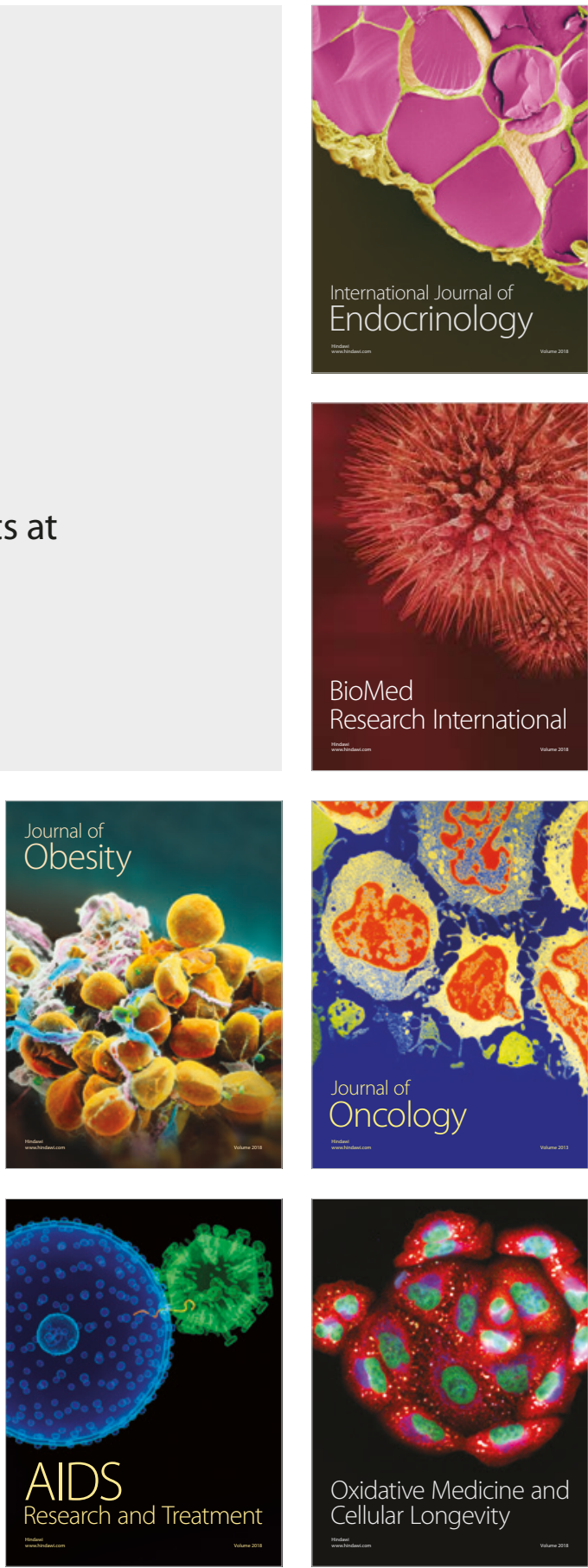